\title{
Dokumentalne portrety kobiet w filmach Ireny Kamieńskiej
}

Irena Kamieńska (1928-2016) była niewątpliwie jedną z najważniejszych polskich i europejskich dokumentalistek. Bogactwo tematów, które podejmowała, wskazuje nie tylko na nieustającą ciekawość świata i człowieka, ale również na ewolucję jej twórczości — od tematów zaangażowanych i społecznikowskich w kierunku kameralnej tematyki religijnej i biograficznej. Wyjątkowo różnorodne (także na tle twórczości innych dokumentalistów) problemy poruszane przez Kamieńską są świadectwem pogłębionej i wielowarstwowej eksploracji rzeczywistości w wielu jej przejawach i aspektach.

Dla Kamieńskiej najważniejszy był człowiek, jego psychika i niepowtarzalny los. Podczas realizacji dokumentów istotne dla reżyserki było wytworzenie klimatu zaufania, szczerości, swoistej temperatury emocjonalnej umożliwiającej pełne porozumienie z pojedynczym człowiekiem czy wybraną grupą społeczną ${ }^{1}$. Istotny dla poznania bohatera był proces dokumentacji, o którym reżyserka mówiła:

Nigdy nie rozmawiam podczas dokumentacji o sprawie podstawowej, która mnie będzie interesowała przed kamerą. Rozmawiam o innych sprawach, by się zorientować, jaki ten bohater jest, jak mówi i co ma do powiedzenia w sensie merytorycznym, ale nie tak, żeby zrobił „próbę wypowiedzi”. Ale żeby człowiek mówił do mnie, muszę do niego mówić, w sposób przyjazny, tak że on zobaczy, że mnie to naprawdę interesuje, co jego boli, czy co go cieszy, co chce mi przekazać. To jest kontakt bezpośredni z człowiekiem, to nie jest reżyseria. Nie wyobrażam sobie zrobienia takiego filmu, gdzie powiedziałabym: „Niech państwo usiądą i porozmawiają na ten temat” - chyba nic z tego by nie wyszło. W filmie dokumentalnym trzeba dostosować się do bohatera - trzeba tak robić, żeby to, co on chce nam przekazać, było dla niego najważniejsze, tak trzeba z nim rozmawiać i takie sytuacje wynajdywać, w których

${ }^{1}$ I. Kamieńska, Samotność młodych, „Ekran” 1969, nr 16, s. 17. 
on chce przekazać swoją sprawę, nie bacząc na to, czego my chcemy od niego, czy my go filmujemy, czy go nie filmujemy. Zawsze sprawa musi być ważniejsza niż film i wtedy można osiągnąć dobre rezultaty².

I gdzie indziej:

Trzeba swoich bohaterów dobrze poznać, nie na tyle, by to deformowało spojrzenie filmowca. Przed zdjęciami stosuję swoistą „rozgrzewkę”, nie dopuszczam jednak, by zdarzyły się jakieś ważne sprawy, zanim kamera będzie mogła je zanotować. To, co znajdzie się w filmie, jest efektem niesłychanie natężonej pracy na planie. To właśnie jedna z cech dokumentu: nigdy nie można zrobić próby ujęcia, notujemy na gorąco, w pośpiechu, by nie stracić niczego ważnego - co obserwujemy bądź co sprowokowaliśmy ${ }^{3}$.

Realizatorka miała świadomość etycznych granic, które powinien respektować dokumentalista. Na pytanie, jak dalece można wkroczyć w ludzką prawdę, odpowiedziała:

Tutaj rzeczywiście trzeba mieć wyczucie i odpowiedzialność, i jakąś postawę wobec drugiego człowieka, można zrobić ogromną krzywdę. Nie wystarczy, że się bohater zgodzi, często sobie bowiem nie zdaje sprawy, co to znaczy, że on się całkowicie uzewnętrzni przed kamerą. Nie zdaje sobie zupełnie sprawy. To my musimy wiedzieć, jakie są konsekwencje, i po prostu do tej granicy dojść, która nikomu nie robi krzywdy ${ }^{4}$.

Dla autorki Robotnic kontakt $\mathrm{z}$ bohaterami był doświadczeniem nie tylko zawodowym: „Robiąc filmy dokumentalne, wzbogacam swoje życie o życie innych ludzi, moich bohaterów, o problemy innych ludzi, o sprawy, z którymi nigdy bym się nie spotkała, gdyby nie film" ${ }^{5}$. Nie oznaczało to jednak stworzenia bliskiej relacji z bohaterem (wyjątkiem pozostaje długoletnia znajomość z bohaterką debiutu Elżbietą Orzyłowską-Łęczycką). W audycji radiowej z 2002 roku Kamieńska przyznała:

Nigdy nie doprowadzałam do tego, żeby mnie moi bohaterowie pokochali, nawet tego nie chciałam, dlatego że uznałam, że to dla nich i dla mnie jest w efekcie krępujące. Oni mają swoje życie, oni chcieli mi opowiedzieć czy zaprezentować fragmenty własnego życia i ja to sfilmowałam. W momencie, kiedy skończyłam swoją pracę, to rozstajemy się po prostu ${ }^{6}$.

Reżyserka, choć zainteresowana psychologią człowieka, nigdy nie odważyła się zrealizować dokumentu, który penetrowałby skomplikowany świat wewnętrzny bohatera. To prawda, że lubiła portretować ludzi (szczególnie pasjonatów), jednak w jej filmach wyczuwalny jest bezpieczny dystans w sposobie przedstawiania bohatera. W rozmowie prywatnej ze mną autorka Robotnic przyznała, że brakowało jej cierpliwości do zgłębiania historii pojedynczego człowieka, w przeciwieństwie do Kazimie-

${ }^{2}$ Irena Kamieńska, audycja Polskiego Radia, cykl: „Tropem dokumentu”, autor audycji: Michał Bielawski, emisja: 4 listopada 2002.

${ }^{3}$ Rozmowy z realizatorami. Z Irena Kamieńska rozmawiała Elżbieta-Smoleń-Wasilewska, „Kamera” 1969, nr 4, s. 13.

${ }^{4}$ Wypowiedź Ireny Kamieńskiej dla stacji Kino Polska, materiał przed montażem.

${ }^{5}$ I. Kamieńska, Życiem innych wzbogacam własne, [w:] Chetmska 21. 50 lat Wytwórni Filmów Dokumentalnych i Fabularnych w Warszawie, red. B. Janicka, A. Kołodyński, Warszawa 2000, s. 260.

${ }^{6}$ Irena Kamieńska, audycja... 
rza Karabasza znanego z uprawiania cierpliwej obserwacji. Dla Kamieńskiej priorytetem była „sprawa”, konkretny problem, w jaki uwikłany był bohater.

Problematyką wiodącą w twórczości Kamieńskiej jest sytuacja kobiet. W ramach tej tematyki można wyróżnić dwa nurty — jeden przedstawia kobiety aktywne i entuzjastyczne, drugi - zrezygnowane i bezradne. Istotnym tłem dla dokumentalnych portretów kobiet pozostaje sytuacja ekonomiczna i polityczna poszczególnych dekad PRL-u. Czasy, w jakich żyły bohaterki, często bowiem determinują ich wybory życiowe, stosunek do siebie i świata. Dokumentem, który zapoczątkował problematykę kobiet i jednocześnie wyznaczył pierwszy nurt, był debiut Dzień dobry, dzieci (1966). Elżbieta Orzyłowska, pochodząca z Radomyśli absolwentka studium nauczycielskiego, pierwszą pracę dostała we wsi Łęczycki w Siedleckiem. Reżyserkę zainspirowała pełna entuzjazmu młoda kobieta:

Interesowało mnie to bardzo, jak ona przeżyje te pierwsze dni swojej pracy. Dwie debiutantki stają naprzeciwko siebie. Bardzo ją polubiłam i zobaczyłam, że to wartościowa dziewczyna. Znakomicie sobie radziła, chociaż miała tam ogromne trudności i opór środowiska był wielki, ponieważ ludzie nie byli przyzwyczajeni do tego, że dzieci mają się przyzwoicie uczyć. Tylko tak chodziły do szkoły, bo chodziły. Ona to wszystko przewalczyła dzięki swojemu entuzjazmowi, głębokiemu przekonaniu do tego, co ma zrobić. Wyszła obronną ręką z tej próby. Ona w każdej chwili musiała zadawać sobie pytania, co dalej. Bo nie była przecież tak przygotowana od strony pedagogicznej, żeby na wszystko znaleźć odpowiedź. Była świeżym nauczycielem. [...] Zrobiła bardzo dużo dla tej wsi i dla tych dzieci biednych ${ }^{7}$.

Reżyserce wyraźnie imponowała pasja nauczycielki, dlatego większość zdjęć z udziałem bohaterki upamiętnia ją w działaniu, w trakcie lekcji, zabawy z dziećmi czy rozmowy z rodzicami. Podobnie entuzjastyczną postacią w galerii kobiet portretowanych przez Kamieńską była Lucyna Maksimiak ze wsi Hołowienki, bohaterka filmu Następny punkt programu (1978). Pełna zaangażowania i optymizmu druhna oddziału strażackiego zderza się z peerelowską rzeczywistością - pasywnością, ignorancją władz (w urzędach nikogo nie można zastać) i typową „jakością" pracy w PRL-u (ekipa naprawiająca słupy elektryczne zamiast pracować, piła alkohol). Mimo tych trudności udaje się zorganizować Lucynie Maksimiak ważną dla tej społeczności uroczystość jubileuszową.

W oświatowym filmie Tak wiele do zrobienia (1977) Kamieńska przygląda się z kolei grupie uczestniczek kilkumiesięcznego kursu na uniwersytecie ludowym w Klenicy. Kobiety biorą udział w zajęciach praktycznych i teoretycznych, dzięki którym mogą rozwijać swoje umiejętności, rozbudzać się intelektualnie i przygotować do pracy w lokalnych ośrodkach kulturalnych. Reżyserka po raz ostatni portretuje aktywne kobiety w 1991 roku w Misjonarkach miłości, zrealizowanych wspólnie z Jadwigą Zajiček. Dokument kręcony w technice VHS z jednej strony pokazuje życie codzienne sióstr niosących pomoc najuboższym, odrzuconym i samotnym, z drugiej charyzmat wspólnoty, który przeżywają podczas pobytu w Warszawie Matki Teresy

\footnotetext{
7 Wypowiedź Ireny Kamieńskiej dla stacji Kino Polska, materiał przed montażem.
} 
z Kalkuty. Wszystko, co robią siostry, jest formą uwielbienia Boga, które trwa nieprzerwanie - w modlitwie i pracy. Realizatorki zrezygnowały z formuły wywiadów na rzecz obserwacji zarówno codzienności sióstr, jak i uroczystości ich zaślubin. Kamera dyskretnie pokazuje ich sylwetki i twarze skupione podczas mszy z udziałem Matki Teresy. Kamieńskiej udało się ukazać dwa ważne aspekty życia misjonarek miłości: vita activa i vita contemplativa.

Zakonnice ze zgromadzenia misjonarek miłości swoją aktywnością i zapałem niesienia pomocy przypominają kobiety z wcześniejszych filmów Kamieńskiej - chociażby Elżbietę Orzyłowską-Łęczycką i Lucynę Maksimiak. Wszystkim im przyświecała idea poprawy świata wokół siebie.

Skrajnie odmienną perspektywę przyjmują kobiety z innych dokumentów Kamieńskiej. Wyspa kobiet (1968), Robotnice (1980) i Dzień za dniem (1988) reprezentują drugi sposób portretowania kobiet — bohaterki są pesymistyczne, bezsilne, pozbawione nadziei.

Życie robotnic z Wyspy kobiet sprowadza się $\mathrm{w}$ dużej mierze do pracy w fabryce obuwia i do mało komfortowej egzystencji w hotelu robotniczym, gdzie mieszkają w wieloosobowych pokojach, ze wspólną łazienką, pełniącą także funkcję pralni. A przyjechały przecież do miasta, jak informuje komentarz, gdyż „chcą spotkać wielką szansę swego życia. Tę, która nada sens codzienności i spełni odwieczne kobiece marzenia" ${ }^{8}$. Mieszkanie w hotelu robotniczym pociągało za sobą szereg konsekwencji dla życia osobistego: brak kontaktów towarzyskich, niemożność założenia rodziny, pogłębiające się poczucie wyobcowania. Kamieńską interesował psychologiczny wymiar problemu, stąd mamy silnie zindywidualizowane portrety bohaterek i pogłębioną obserwację. Reżyserka „bada kamerą" sferę prywatności, ale w sposób nieprzekraczający granicy intymności. Ukazuje bohaterki w scenach wróżenia, przygotowania do zabawy; słucha ich wyznań. Obserwuje ich skromne mieszkania, codzienne rytuały - mycia, gotowania, sprzątania - sceny te ewokują poczucie tęsknoty, niespełnienia oraz pustki. W konfrontacji z automatyzacją pracy i gorzką sceną zabawy składają się na obraz życia bez perspektyw.

Kamieńska we wstrząsających Robotnicach przedstawiła jeszcze bardziej dramatyczną sytuację kobiet w PRL-u. Jak wspominała, jej bohaterki:

Czuły się upokorzone nie tyle warunkami, w jakich muszą pracować - kurzem, wilgocią, hałasem, smrodem, straszliwym prymitywem, lecz przede wszystkim stosunkiem do nich, ich próśb i postulatów miejscowego establishmentu, dyrekcji zakładów, władz partyjnych. Nikt ich nie chciał słuchać. Nikt im nie chciał pomóc. Owo poczucie bezsilności, niemożności, kompletny brak jakiejkolwiek komunikacji między „dołem” a „górą", wreszcie fakt, że „góra” umie tylko żądać, nic nie dając w zamian — przerodziło się w poczucie stałego zagrożenia. I jednocześnie w poczucie głębokiej niewiary w możliwość jakichkolwiek zmian? ${ }^{9}$.

\footnotetext{
${ }^{8}$ Lista montażowa filmu.

9 Świadomy wybór. Rozmowa z reż. Ireną Kamieńską, „Zwierciadło” 1981, nr 29, s. 12.
} 
Pracownice Zakładów Lniarskich w Krośnie, często mające za sobą dwadzieścia czy trzydzieści lat pracy, wysuwały podstawowe żądania, które i tak okazywały się zbyt problematyczne - potrzebowały lekkiej odzieży ochronnej (ich fartuchy są zbyt ciężkie), wygodnych butów (a nie drewniaków), skutecznych rozwiązań, które pozwoliłyby swobodniej oddychać (zapylenie jest ogromne, a maski w ogóle nie chronią), ciepłej wody i mydła. Kobiety te miały odgórnie narzuconą konieczność pracy co drugą sobotę, podczas gdy już ośmiogodzinny dzień pracy w tak ciężkich warunkach i obowiązki domowe stanowiły ogromne obciążenie. Kobiety mają poczucie głębokiej niesprawiedliwości, ich egzystencja toczy się na poziomie minimum, podczas gdy w pobliżu kierownictwo korzysta $z$ wygód we wspaniałym biurowcu. Oficjalna propaganda utrzymywała, że w Polsce wiele się robi, by ułatwić kobietom życie. Jednak warunki, w jakich pracowały robotnice w przędzalni, dowodzą rozbieżności między partyjnymi deklaracjami a rzeczywistością. Kamieńska uważnie i cierpliwie wysłuchuje postulatów kobiet, wyraźnie im sprzyja i współczuje, ową bliskość podkreśla pozycja kamery - sprzęt umieszczony jest w takiej pozycji, jakby reżyserka siedziała przy stole wraz z kobietami. Operator Krzysztof Pakulski, portretując robotnice podczas pracy, pokazał w zbliżeniach ich twarze zakryte maskami przeciwpyłowymi, drepczące w wodzie nogi w drewniakach, ubrudzone ręce oraz wszechobecny pył i hałas. Dramatyzm sytuacji robotnic uzyskany jest poprzez kontrast: huk maszyn - milczenie prządek; widok pracujących maszyn - ludzkie zmęczone twarze. Na przemian oglądamy sceny z przędzalni, podczas odpoczynku i po pracy (ubieranie). Kamera często portretuje milczące kobiety, nawet jeśli z offu słychać komentarz. Ascetyczne środki wyrazu, jakich użył Pakulski (wysoko kontrastowe czarno-białe zdjęcia wydobywały materialność wszechobecnego kurzu), i oszczędne kadrowanie oddają warunki panujące w zakładzie - prymitywne i uciążliwe, rodem z dziewiętnastowiecznej fabryki. Podczas gdy robotnice z Krosna wyrażają swoje niezadowolenie i cichy bunt, bliźniaczki z dokumentu Dzień za dniem, które za moment mają odejść na emeryturę po trzydziestu sześciu latach wyniszczającej pracy przy przeładunku cegieł, nie czują goryczy, zaakceptowały bezkrytycznie to, co „ofiarował” im system. Mimo zmieniających się przywódców, polityki i sytuacji gospodarczej, bohaterki Dnia za dniem jakby zatrzymały się w czasie, wykonując przez ponad trzy dekady tę samą pracę.

„Życie zmieniło je w rodzaj robotów... To, co zarabiały, wystarczyło im właściwie tylko na jedzenie. A więc z jednej strony prawda o ich życiu - a z drugiej te cyniczne hasła"10 - Kamieńska wymownie wskazuje, że życie sióstr jest zaprzeczeniem obietnic złożonych przez komunistów. Początkowo nie mogła zaakceptować obojętności swoich bohaterek: "Ten film rodził się z buntu przeciwko bierności tych kobiet”"11. Dopiero po zakończeniu filmu zaczęła im współczuć: „Zdałam sobie sprawę, jak nie-

\footnotetext{
${ }^{10}$ I. Kamieńska, Żywe roboty, [w:] Chetmska 21..., s. 264.

11 Ibidem.
} 
szczęśliwe było ich życie. Bezradność, samotność, żadnych perspektyw. To nie ich wina, że życie ukształtowało je na takie "roboty «"12. Maria Zmarz-Koczanowicz podkreśla, że bohaterki są samotne, pozbawione pomocy, wparcia i nadziei ${ }^{13}$. Utraciły wszelkie atrybuty kobiecości - ich obrzmiałe, zmaskulinizowane, owinięte w chusty twarze wyrażają jedynie zmęczenie i apatię. Bliźniaczki skontrastowane zostały z entuzjastycznymi, uśmiechniętymi twarzami kobiet $\mathrm{z}$ kronik filmowych - uczestniczek odbudowy kraju i nowej politycznej rzeczywistości. Za pomocą tego zabiegu reżyserka wskazuje na fałsz i pustkę propagandowych haseł. Ubrane w spodnie i kufajki, bohaterki filmu Dzień za dniem, pozbawione są indywidualności, cech płci, przypominają — jak pisze Mikołaj Jazdon — groteskowe portrety Jerzego Dudy Gracza ${ }^{14}$.

Irena Kamieńska i montażystka Jadwiga Zajiček zbudowały swój dokument na kontrastach - katatonia jazdy do pracy zderzona została $\mathrm{z}$ entuzjazmem haseł; szare blokowiska z powojenną, propagandową euforią odbudowy kraju; zmęczone, szare twarze starych kobiet $\mathrm{z}$ roześmianymi i pięknymi ujęciami warszawskich ceglarek przy pracy; leniwa postawa kierowcy z niezwykle ciężką pracą kobiet. Dzięki takim montażowym rozwiązaniom widzimy rozdźwięk między ponurymi realiami i propagandową wersją rzeczywistości. Operator Krzysztof Pakulski również dokonał istotnych estetycznych wyborów - filmując bohaterki z często niespotykanych ustawień kamery, „uwięził” je pośród cegieł, a także w szoferce, kadrując je w półzbliżeniu podczas jazdy ciężarówką. Zaspane, zmęczone i odrętwiałe od mozołu kobiety kołyszą się w rytm jazdy w milczeniu, nie mają siły ze sobą rozmawiać. Znaczące jest, że ani razu bohaterki nie patrzą w stronę kamery, w samochodzie mają spuszczony wzrok, podczas zdjęć kręconych przy wyładunku zaabsorbowane są pracą. Jedynie w ostatnim kadrze Kamieńska ustawiła robotnice naprzeciwko kamery. Ważne dla zrozumienia finalnej sceny jest montażowe zestawienie hasła „Praca rzetelna i szczera zrobi z ciebie bohatera" $\mathrm{z}$ portretem robotnic stojących na placu budowy w zimowy, śnieżny dzień. Kamieńska, konfrontując propagandowy slogan z trudem życia bohaterek, ukazała kłamstwo systemu komunistycznego, który sprawił, że kobiety zamiast bohaterkami stały się niewolnicami. Milczenie sióstr jest wymowne - propaganda uczyniła z nich maszyny do pracy, którym odebrano prawo głosu. Dzień $z a$ dniem jest trafnym i dobitnym podsumowaniem całego okresu PRL-u, obnaża system, którego bliźniaczki nigdy nie podały w wątpliwość. Bezradne kobiety, które Kamieńska często portretowała, były przeciwieństwem jej własnej postawy — kobiety silnej, świadomej siebie.

Kino dokumentalne było dla Ireny Kamieńskiej pasją i spełnieniem pragnienia o połączeniu pracy z życiem. W 2009 roku Stowarzyszenie Filmowców Polskich

12 Ibidem, s. 265.

${ }^{13}$ M. Zmarz-Koczanowicz, Kobiety o kobietach w polskim dokumencie: szkic o kilku filmach Krystyny Gryczełowskiej i Ireny Kamieńskiej, „Kwartalnik Filmowy”1999, nr 20-25, s. 194.

${ }^{14}$ M. Jazdon, Książeczka dołączona do albumu z płytami DVD trzech dokumentalistek: Krystyny Gryczełowskiej, Danuty Halladin i Ireny Kamieńskiej, „Polska Szkoła Dokumentu”, Warszawa 2009. 
przyznało Irenie Kamieńskiej nagrodę za wybitne osiągnięcia artystyczne, a w 2014 roku Międzynarodowy Festiwal Filmów Dokumentalnych OFF CINEMA w Poznaniu wyróżnił dokonania dokumentalistki Platynowym Zamkiem. Irena Kamieńska zmarła 3 kwietnia 2016 roku w Warszawie w wieku 88 lat $^{15}$.

Fragmenty tekstu $w$ zmienionej wersji pochodza $z$ monografii mojego autorstwa Człowiek, zbiorowość, pamięć w filmach dokumentalnych Ireny Kamieńskiej, Kraków 2016.

\section{Bibliografia}

Jazdon M., Książeczka dołączona do albumu z płytami DVD trzech dokumentalistek: Krystyny Gryczełowskiej, Danuty Halladin i Ireny Kamieńskiej, „Polska Szkoła Dokumentu”, Warszawa 2009.

Kamieńska I., Samotność młodych, „Ekran” 1969, nr 16.

Kamieńska I., Życiem innych wzbogacam własne, [w:] Chełmska 21. 50 lat Wytwórni Filmów Dokumentalnych i Fabularnych w Warszawie, red. B. Janicka, A. Kołodyński, Warszawa 2000.

Kamieńska I., Żywe roboty, [w:] Chełmska 21. 50 lat Wytwórni Filmów Dokumentalnych i Fabularnych $w$ Warszawie, red. B. Janicka, A. Kołodyński, Warszawa 2000.

Rozmowy z realizatorami. Z Ireną Kamieńską rozmawiała Elżbieta-Smoleń-Wasilewska, „Kamera” 1969, nr 4.

Świadomy wybór. Rozmowa z reż. Ireną Kamieńską, „Zwierciadło” 1981, nr 29.

Zmarz-Koczanowicz M., Kobiety o kobietach w polskim dokumencie: szkic o kilku filmach Krystyny Gryczełowskiej i Ireny Kamieńskiej, „Kwartalnik Filmowy” 1999, nr 20-25.

\section{Documentary portraits of women in Irena Kamieńska's films}

Summary

The author presents one of the main topics in Irena Kamieńska's documentary oeuvre - the problems of women. In the article she discusses two kinds of female portraits created by the director - strong and full of enthusiasm (Good Morning, Children, Next Point on the Agenda), and helpless, without any hope (Workers; Day After Day). Of crucial importance is the sociological-historical context, referred to by the author, which makes it possible to take a broader view on the conditions in which the protagonists of Kamieńska's documentaries lived. In addition, the author discusses the director's attitude to her protagonists.

Keywords: document, communism, women, work, passion

${ }^{15}$ Irena Kamieńska została pochowana na Cmentarzu Ewangelicko-Augsburskim w Warszawie, jej grób znajduje się na alei 30, nr 99. 